\title{
LIST OF FIGURES
}

1.1 East Asia

page 3

1.2 Shanghai, 1937

8.1 Patterns of Japanese residence in the Korean peninsula, 1876-1945

8.2 The distribution of Japanese settlement in Korea, c. 1940. Source After Hermann Lautensach, Korea: a Geography based on the Author's Travels and Literature, trans. K. and E. Dege, Leipzig, Koehler, 1945; reprinted Berlin, Springer, 1988

8.3 Reappearing Koreans in the 'open port' of Mokp'o.

Source Lautensach, Korea, fig. 79, p. 372

8.4 A new town in northern Korea: Nanam. Source

Lautensach, Korea, fig. 41, p. 209

8.5 Split settlement in Wônsan. Source Lautensach, Korea, fig. 65 , p. 307

9.1 Geographical origin of Shanghai's Japanese residents, 1943.

Source Kai-in meibo (List of Members [of the Japanese Club]), Shanghai, Shanhai nippon kurabu, 1944

9.2 'Little Tokyo': Japanese neighbourhood associations, 1938.

Source Shanhai nihoniin kakuro rengokai no enkaku to jiseji (Events and Evolution of the Japanese Street Unions in Shanghai), Shanghai, Shanhai nihonjin kakuro rengokai, 1939, pp. 19-55

9.3 Year of foundation of Japanese firms, 1941 